\title{
A hydrodynamic model for Galveston Bay and the shelf in the northern Gulf of Mexico
}

\author{
Jiabi Du ${ }^{1}$, Kyeong Park ${ }^{1}$, Jian Shen ${ }^{2}$, Yinglong J. Zhang ${ }^{2}$, Xin Yu ${ }^{2}$, Fei Ye $^{2}$, Zhengui Wang ${ }^{3}$, and Nancy N. Rabalais ${ }^{4}$ \\ ${ }^{1}$ Department of Marine Sciences, Texas A\&M University at Galveston, Galveston, TX 77554, USA \\ ${ }^{2}$ Virginia Institute of Marine Science, College of William and Mary, Gloucester, VA 23062, USA \\ ${ }^{3}$ School of Marine Sciences, University of Maine, Orono, ME 04469, USA \\ ${ }^{4}$ Louisiana State University, Baton Rouge, LA 70803, USA
}

Correspondence: Jiabi Du (jdu@tamug.edu)

Received: 9 February 2019 - Discussion started: 4 March 2019

Revised: 15 May 2019 - Accepted: 27 June 2019 - Published: 17 July 2019

\begin{abstract}
A 3-D unstructured-grid hydrodynamic model for the northern Gulf of Mexico was developed, with a hybrid $s-z$ vertical grid and high-resolution horizontal grid for the main estuarine systems along the Texas-Louisiana coast. This model, based on the Semi-implicit Cross-scale Hydroscience Integrated System Model (SCHISM), is driven by the observed river discharge, reanalysis atmospheric forcing, and open boundary conditions from global HYCOM output. The model reproduces the temporal and spatial variation of observed water level, salinity, temperature, and current velocity in Galveston Bay and on the shelf. The validated model was applied to examine the remote influence of neighboring large rivers, specifically the Mississippi-Atchafalaya River (MAR) system, on salinity, stratification, vertical mixing, and longshore transport along the Texas coast. Numerical experiments reveal that the MAR discharge could significantly decrease the salinity and change the stratification and vertical mixing on the inner Texas shelf. It would take about 25 and $50 \mathrm{~d}$ for the MAR discharge to reach the mouth of Galveston Bay and Port Aransas, respectively. The influence of the MAR discharge is sensitive to the wind field. Winter wind constrains the MAR freshwater to form a narrow lower-salinity band against the shore from the Mississippi Delta all the way to the southwestern Texas coast, while summer wind reduces the downcoast longshore transport significantly, weakening the influence of the MAR discharge on surface salinity along Texas coast. However, summer wind causes a much stronger stratification on the Texas shelf, leading to a weaker vertical mixing. The decrease in salinity of up to $10 \mathrm{psu}$ at the mouth of Galveston Bay due to the MAR
\end{abstract}

discharge results in a decrease in horizontal density gradient, a decrease in the salt flux, and a weakened estuarine circulation and estuarine-ocean exchange. We highlight the flexibility of the model and its capability to simulate not only estuarine dynamics and shelf-wide transport, but also the interactions between them.

\section{Introduction}

The northern Gulf of Mexico (GoM) is characterized by complicated shelf and coastal processes including multiple river plumes with varying spatial scales, a highly energetic deep current due to steep slopes, upwelling in response to alongshore wind, and mesoscale eddies derived from the Loop Current in the Gulf Stream (Oey et al., 2005; Dukhovskoy et al., 2009; Dzwonkowski et al., 2015; Barkan et al., 2017). Freshwater from the Mississippi-Atchafalaya River (MAR) basin introduces excess nutrients and terminates amidst one of the United States' most productive fishery regions and the location of the largest zone of hypoxia in the western Atlantic Ocean (Rabalais et al., 1996, 2002; Bianchi et al., 2010). The physical, biological, and ecological processes in the region have been attracting increasing attention, given its sensitive response to large-scale climate variation, accelerated sea-level rise, and extensive anthropogenic interventions (Justić et al., 1996; Rabalais et al., 2007).

Understanding the interaction and coupling between regional-scale ocean dynamics and local-scale estuarine processes is of great interest. Many observational (in situ and 
satellite) (e.g., Cochrane and Kelly, 1986; DiMarco et al., 2000; Chu et al., 2005) and numerical modeling (e.g., Zavala-Hidalgo et al., 2003, 2006; Hetland and Dimarco, 2008; Fennel et al., 2011; Gierach et al., 2013; Huang et al., 2013) studies have been conducted for the shelf of the GoM. Hetland and Dimarco (2008) configured a hydrodynamic model based on the Regional Ocean Modelling System (ROMS; Shchepetkin and McWilliams, 2005) for the Texas-Louisiana shelf, which has been used for subsequent physical and/or biological studies (Fennel et al., 2011; Laurent et al., 2012; Rong et al., 2014). Zhang et al. (2012) extended the model domain westward to cover the entire Texas coast. Wang and Justić (2009) applied the Finite-Volume Coast Ocean Model (FVCOM; Chen et al., 2006) over a similar domain to that of Hetland and Dimarco (2008). Lehrter et al. (2013) applied the Navy Coastal Ocean Model (NCOM; Martin, 2000) over the inner Louisiana shelf with a focus on Mississippi River plumes. In addition, there were modeling studies for larger domains such as the entire GoM (Oey and Lee, 2002; Wang et al., 2003; Zavala-Hidalgo et al., 2003). For example, Zavala-Hidalgo (2003) used the NCOM to investigate the seasonally varying shelf circulation in the western shelf of the GoM. Bracco et al. (2016) used the ROMS to examine the mesoscale and sub-mesoscale circulation in the northern GoM.

Other hydrodynamic modeling studies focused on specific estuarine systems such as Galveston Bay (Rayson et al., 2015; Rego and Li, 2010; Sebastian et al., 2014), Mobile Bay (Kim and Park, 2012; Du et al., 2018a), and Choctawhatchee Bay (Kuitenbrouwer et al., 2018). These models tend to have smaller domains, including the target estuary and the inner shelf just outside the estuary. The dynamics in these coastal bays are affected by both large-scale shelf conditions and localized small-scale geometric and bathymetric features such as narrow but deep ship channels, seaward-extending jetties, and offshore sandbars, which are typically on the order of 10 to $100 \mathrm{~m}$. Including both the estuarine and shelf processes and their interactions is critically important for a more comprehensive understanding of regional physical oceanography in the northern GoM. For this purpose, cross-scale models with unstructured grids have become an attractive option.

The hydrodynamic conditions (e.g., salinity, stratification, and vertical mixing) over the Louisiana shelf are known to be dominated by the influence of MAR plumes (Lehrter et al., 2013; Rong et al., 2014; Androulidakis et al., 2015). However, their effect on the salinity on the Texas shelf has not been well documented. Measurements at Port Aransas ( $600 \mathrm{~km}$ to the west of Atchafalaya River) show an evident seasonal cycle, with higher salinity during the summer and lower salinity during the winter (Bauer, 2002). Is this seasonality related to the seasonal variation of the MAR discharge and/or to the seasonality of the shelf transport? A broader question may be how the MAR discharge affects the salinity along the Texas coast. Furthermore, it is also important to understand the temporal and spatial scales with which the salinity at or near the mouth of an estuarine system respond to river plumes from neighboring river systems. For example, how long will it take for the salinity at the Texas coast to respond to a pulse of freshwater input from the MAR? This timescale in comparison to the timescales of estuarine processes (e.g., recovery timescale from storm disturbance) will allow one to determine whether the remote influence of neighboring major rivers is necessary to consider.

Here, we present a model for the northern GoM with a domain including all the major estuaries, as well as the shelf, and a fine-resolution grid for local estuaries to resolve smallscale bathymetric or geometric features such as ship channels and dikes. Using Galveston Bay as an example, we highlight the flexibility and capability of the model to simulate both estuarine and shelf dynamics. We demonstrate the importance of the interactions among estuaries and the shelf by investigating the remote influence of the MAR discharge on the hydrodynamics along the Texas coast.

\section{Methodology}

\subsection{Model description}

We employed the Semi-implicit Cross-scale Hydroscience Integrated System Model (SCHISM; Zhang et al., 2015, 2016), an open-source community-supported modeling system derived from the early SELFE model (Zhang and Baptista, 2008). SCHISM uses a highly efficient semiimplicit finite-element and finite-volume method with a Eulerian-Lagrangian algorithm to solve the turbulenceaveraged Navier-Stokes equations under the hydrostatic approximation. It uses the generic length-scale model of Umlauf and Burchard (2003) with the stability function of Kantha and Clayson (1994) for turbulence closure. One of the major advantages of the model is that it has the capability of employing a very flexible vertical grid system, robustly and faithfully resolving the complex topography in estuarine and oceanic systems without any smoothing (Zhang et al., 2016; Stanev et al., 2017; Du et al., 2018b; Ye et al., 2018). A more detailed description of the SCHISM, including the governing equations, horizontal and vertical grids, numerical solution methods, and boundary conditions, can be found in Zhang et al. (2015, 2016).

\subsection{Model domain and grid system}

The model domain covers the Texas, Louisiana, Mississippi, and Alabama coasts, including the shelf as well as major estuaries (e.g., Mobile Bay, Mississippi River, Atchafalaya River, Sabine Lake, Galveston Bay, Matagorda Bay, and Corpus Christi Bay) (Fig. 1). The domain also includes part of the deep ocean to set the open boundary far away from the shelf to avoid imposing boundary conditions at topographically complex locations. The horizontal grid contains 142972 surface elements (triangular and quadrangular), with 


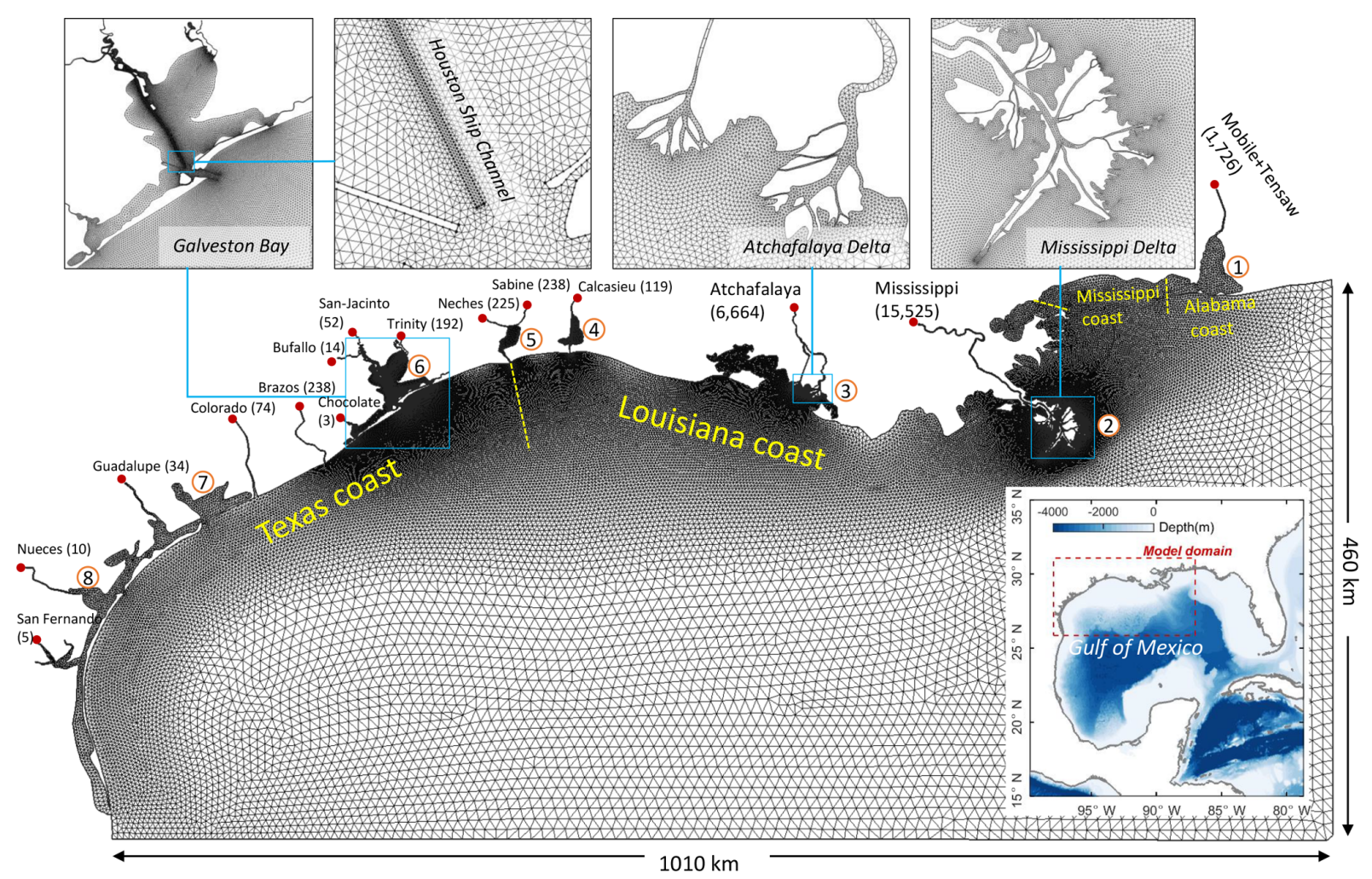

Figure 1. The model domain and the horizontal grid, with the upper panels showing zoomed-in views of selected coastal systems. Locations of major river inputs are indicated with red dots, with the associated mean river discharges $\left(\mathrm{m}^{3} \mathrm{~s}^{-1}\right)$ shown in parentheses. Major estuarine bay systems in the model domain include Mobile Bay (1), Mississippi River (2), Atchafalaya River (3), Calcasieu Lake (4), Sabine Lake (5), Galveston Bay (6), Matagorda Bay (7), and Corpus Christi Bay (8).

the resolution ranging from $10 \mathrm{~km}$ in the open ocean to $2.5 \mathrm{~km}$ on average on the shelf (shallower than $200 \mathrm{~m}$ ) to $40 \mathrm{~m}$ at the Houston Ship Channel, a narrow but deep channel along the longitudinal axis of Galveston Bay. The fine grid for the ship channel is carefully aligned with the channel orientation in order to accurately simulate the salt intrusion process (Ye et al., 2018). Vertically, a hybrid $s-z$ grid is used, with 10 sigma layers for depths less than $20 \mathrm{~m}$ and another $30 z$ layers for depths from 20 to $4000 \mathrm{~m}(20,25,30$, $35,40,50,60,70,80,90,100,125,150,200,250,300,350$, $400,500,600,700,800,900,1000,1250,1500,2000,2500$, $3000,4000 \mathrm{~m}$ ); shaved cells are automatically added near the bottom in order to faithfully represent the bathymetry and thus the bottom-controlled processes. This hybrid $s-z$ vertical grid enables the model to better capture the stratification in the upper surface layer while keeping the computational cost reasonable for simulations of the deep waters. With a time step of $120 \mathrm{~s}$ and the second-order finite-volume implicit total variation diminishing $\left(\mathrm{TVD}^{2}\right)$ scheme for mass transport, it takes about $24 \mathrm{~h}$ for a 1 -year simulation with 120 processors (Intel Xeon E5-2640 v4).

The bathymetry used in the model is based on the coastal relief model ( 3 arcsec resolution; https://www.ngdc.noaa. gov, last access: 7 November 2019). The local bathymetry in Galveston Bay is augmented by $10 \mathrm{~m}$ resolution digital elevation model (DEM) bathymetric data to resolve the narrow ship channel ( $150 \mathrm{~m}$ wide, $10-15 \mathrm{~m}$ deep) that extends from the bay entrance all the way to the Port of Houston. The bathymetry of the ship channels in other rivers, such as the Mississippi, Atchafalaya, and Sabine, is manually set following National Oceanic and Atmospheric Administration (NOAA) navigational charts. The depth in the model domain ranges from $3400 \mathrm{~m}$ in the deep ocean to less than $1 \mathrm{~m}$ in Galveston Bay (Fig. 2).

\subsection{Forcing conditions}

The model was validated for the 2-year conditions in 20072008 and was forced by the observed river discharge, reanalysis atmospheric forcing, and open boundary conditions from global HYCOM output. Daily freshwater inputs from United States Geological Survey (USGS) gauging stations were specified at 15 river boundaries (Fig. 1). For the Mississippi River, the largest in the study area, river discharge at Baton Rouge, LA (USGS 07374000), was used. For the Atchafalaya River, the second largest, the discharge data at the upper river station (USGS 07381490 at Simmesport, LA) were used, but the data before 2009 at this station are not 

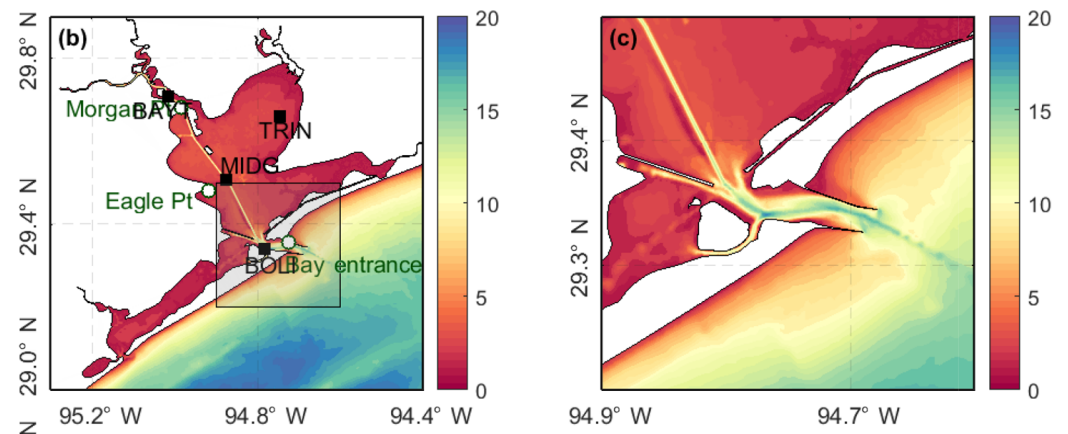

NOAA tidal gauge station

- TWDB salinity monitoring station

A TABS buoy station

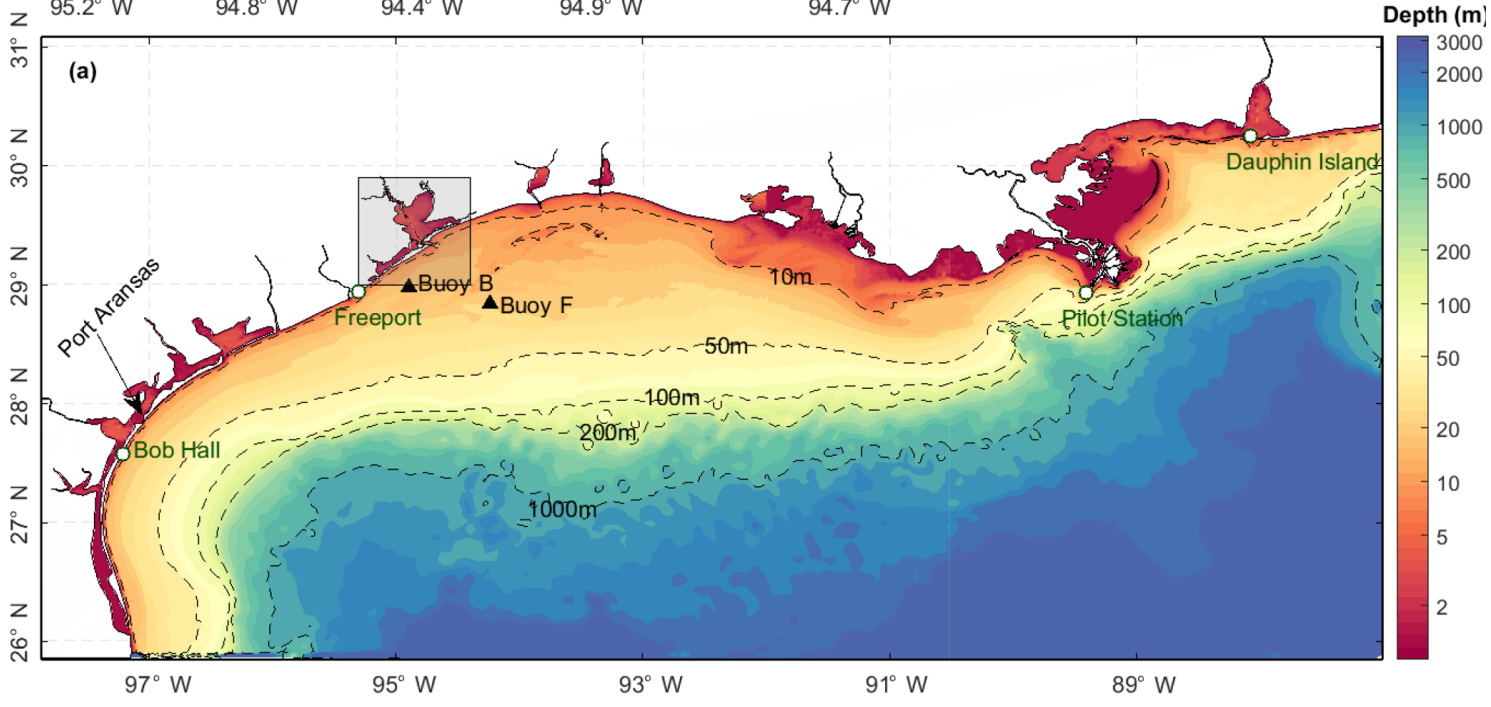

Figure 2. Bathymetry in the model domain showing zoomed-in views (b-c) of Galveston Bay and its main entrance. Note the log scale (a) for depth because of a very wide range of depth over the entire model domain. Also shown are the NOAA tidal gauge stations (open green circles), TWDB (Texas Water Development Board) salinity monitoring stations (solid black circles), and TABS (Texas Automated Buoy System) buoy stations (black solid triangles).

available. However, we found a significant linear relationship between this station and the one near the river mouth (USGS 07381600 at Morgan City, LA) with a $2 \mathrm{~d}$ time lag $\left(r^{2}\right.$ of 0.92) based on the data from 2009 to 2017 . The freshwater discharge estimated at Simmesport using this relationship for 2007-2008 was used to specify the Atchafalaya River freshwater input into the Atchafalaya Bay. For the Trinity River, the major river input for Galveston Bay, river discharge at the lower reach station at Wallisville (USGS 08067252) was used, where the mean river discharge (averaged over April 2014 and April 2018) is about $56 \%$ of that at an upper reach station at Romayor (USGS 08066500). This is because the water from Romayor likely flows into wetlands and water bodies surrounding the main channel of the Trinity River before reaching Wallisville (Lucena and Lee, 2017). The river discharge data before April 2014 at the Wallisville station are not available. Similar to the case for the Atchafalaya River, there is a significant linear relationship between these two stations ( $r^{2}$ of 0.89 with a $4 \mathrm{~d}$ time lag based on the data from 2014 to 2018). The freshwater discharge for 2007-2008 estimated using this relationship was used to specify the Trinity River freshwater input into Galveston Bay. River flows from other rivers were prescribed using the data at the closest USGS stations. Water temperatures at the river boundaries were also based on the data at these USGS stations.

Reanalyzed $0.25^{\circ}$ resolution, 6-hourly atmospheric forcing data, including air temperature, solar radiation, wind, humidity, and pressure at mean sea level, were extracted from the European Centre for Medium-Range Weather Forecasts (ECMWF; https://www.ecmwf.int, last access: 7 November 2019). SCHISM uses the bulk aerodynamic module of Zeng et al. (1998) to estimate heat flux at the air-sea interface. Both harmonic tide and subtidal water level were used to define the ocean boundary condition, with the harmonic tide (M2, S2, K2, N2, O1, Q1, K1, and P1) from the global tidal model FES2014 (Carrere et al., 2015) and the subtidal water level from the low-pass-filtered (cutoff period of $15 \mathrm{~d}$ ) daily global HYCOM output. The model was relaxed during inflow to the HYCOM output at the ocean boundary in terms of salinity, temperature, and velocity. 


\subsection{Numerical experiments}

To investigate the remote influence of the MAR discharge, we conducted three numerical experiments that use the same model configuration as in the realistic 2007-2008 model run except for freshwater discharge, wind forcing, initial salinity condition, and salinity boundary condition. To isolate the influence of the MAR discharge, we considered freshwater discharges (constant long-term means) only for the Mississippi River, Atchafalaya River, and Galveston Bay, with no discharge from other coastal systems. To examine the effect of seasonal wind, we chose the January 2008 and July 2008 winds as representative of winter and summer winds, respectively. The January wind was dominated by northeast-east wind and expected to induce a stronger downcoast (from Louisiana toward Texas) longshore current compared to the predominantly south wind in July (Fig. S1). The initial salinity condition is set to 36 psu throughout the entire domain and for all vertical layers. Salinity at the ocean boundary is set to 36 psu throughout the simulation period.

Differences among the three experiment settings include the following: (1) experiment Jan-G includes only the river discharges into Galveston Bay $\left(259 \mathrm{~m}^{3} \mathrm{~s}^{-1}\right)$ and uses the January 2008 wind; (2) experiment Jan-GAM includes Galveston discharge as well as the MAR discharges $\left(22189 \mathrm{~m}^{3} \mathrm{~s}^{-1}\right.$ ) and uses the January 2008 wind; and (3) experiment Jul-GAM has the same discharges as Jan-GAM but uses the July 2008 wind. In each simulation, the January or July wind was repeated every month, rather than using monthly mean steady wind, in order to take into account the wind variability, which is known to play an important role in shelf circulation (Ohlmann and Niiler, 2005).

\section{Model validation}

The model results for 2007-2008 were compared with observations for water level at seven NOAA tidal gauge stations, salinity at four Texas Water Development Board (TWDB) stations, temperature at three NOAA stations, and current velocity at two Texas Automated Buoy System (TABS) buoys (see Fig. 2 for station locations). Comparisons were made for both total and subtidal ( $48 \mathrm{~h}$ low-pass-filtered) components. For quantitative assessment of the model performance, two indexes were used, model skill (Willmott, 1981) and mean absolute error (MAE):

$$
\begin{aligned}
& \text { Skill }=1-\frac{\sum_{i=1}^{N}\left|X_{\mathrm{mod}}-X_{\mathrm{obs}}\right|^{2}}{\sum_{i=1}^{N}\left(\left|X_{\mathrm{mod}}-\overline{X_{\mathrm{obs}}}\right|+\left|X_{\mathrm{obs}}-\overline{X_{\mathrm{obs}}}\right|\right)^{2}}, \\
& \text { MAE }=\frac{1}{N} \sum_{i=1}^{N}\left|X_{\mathrm{mod}}-X_{\mathrm{obs}}\right|,
\end{aligned}
$$

where $X_{\text {obs }}$ and $X_{\text {mod }}$ are the observed and modeled values, respectively, with the overbar indicating the temporal average over the number of observations $(N)$. The model skill provides an index of model-observation agreement, with a skill of 1 indicating perfect agreement and a skill of 0 indicating complete disagreement. The magnitude of the MAE indicates the average deviation between the model and observations.

\subsection{Water level}

Model-observation comparisons were made for water level at stations along the coast and inside Galveston Bay. Manning's friction coefficient, which is converted to the bottom drag coefficient for the 3-D simulation in the model, was used as a calibration parameter. The model results with a spatially uniform Manning's coefficient of $0.016 \mathrm{~m}^{1 / 3} \mathrm{~s}^{-1}$ show good agreement with the observational data. Overall, the model reproduces both the tidal and subtidal components of water level at tidal gauge stations along the coast as well as inside Galveston Bay (Fig. 3, Table 1, and Fig. S2). The MAE is in the range of 7-8 and 5-7 $\mathrm{cm}$ for the total and subtidal components, respectively. The model skill varies spatially, with relatively low skills (0.88) at Pilot Station and Dauphin Island for the subtidal component and high skills $(\geq 0.94$ ) at the stations on the Texas coast, including Galveston Bay, for both the total and subtidal components. It is interesting to note that the model has also simulated the storm surge well during Hurricane Ike (around day 625), one of the most severe hurricanes to hit the Houston-Galveston area in recent years. When applied to investigate the dramatic estuarine response to Hurricane Harvey (2017) in Galveston Bay, this model successfully reproduced the long-lasting elevated water level inside the bay (Du and Park, 2019a; Du et al., 2019b). Simulation of surface elevation is sensitive to topography, bottom friction, boundary conditions, and atmospheric forcings. Some discrepancies are expected due to the assumption of a spatially uniform Manning's coefficient. Further improvement might be achieved by using spatially varying coefficients, but we did not deem it worth trying, considering the current satisfactory performance of the model. Additional discrepancies may come from the limited spatial and temporal resolution of atmospheric forcings, the accuracy of the bathymetric data, and the reliability of the open boundary conditions from the global HYCOM output.

\subsection{Salinity}

The model reasonably reproduces the observed variation in salinity at stations inside Galveston Bay (Fig. 4 and Table 1). The MAEs are no larger than 3 psu and the model skills range between $0.81-0.93$ and $0.75-0.93$ for the total and subtidal components, respectively. It is important to note that the salinity at the bay mouth under normal (i.e., nonflooding) conditions is sensitive to the longshore transport 
Table 1. Error estimates for model-data comparison for 2007-2008.

\begin{tabular}{|c|c|c|c|c|c|}
\hline \multirow[t]{2}{*}{ Variables } & \multirow[t]{2}{*}{ Station } & \multicolumn{2}{|c|}{ Total } & \multicolumn{2}{|c|}{ Subtidal } \\
\hline & & MAE & Skill & MAE & Skill \\
\hline \multirow[t]{7}{*}{ Water level (cm) } & Morgan's Point & 7.61 & 0.96 & 6.65 & 0.95 \\
\hline & Eagle's Point & 6.87 & 0.96 & 6.13 & 0.96 \\
\hline & Bay Entrance & 7.98 & 0.96 & 6.17 & 0.94 \\
\hline & Freeport & 7.62 & 0.96 & 6.37 & 0.94 \\
\hline & Bob Hall & 6.65 & 0.97 & 5.41 & 0.94 \\
\hline & Pilot Station & 6.23 & 0.95 & 5.36 & 0.88 \\
\hline & Dauphin Island & 7.29 & 0.94 & 6.61 & 0.88 \\
\hline \multirow[t]{4}{*}{ Salinity (psu) } & TRIN $(1.5 \mathrm{~m})^{\mathrm{a}}$ & 2.06 & 0.93 & 2.03 & 0.93 \\
\hline & $\operatorname{BAYT}(2.0 \mathrm{~m})^{\mathrm{a}}$ & 2.69 & 0.87 & 2.59 & 0.87 \\
\hline & $\operatorname{MIDG}(3.1 \mathrm{~m})^{\mathrm{a}}$ & 2.56 & 0.86 & 2.43 & 0.85 \\
\hline & BOLI $(2.9 \mathrm{~m})^{\mathrm{a}}$ & 3.04 & 0.81 & 2.92 & 0.75 \\
\hline \multirow[t]{3}{*}{ Surface temperature $\left({ }^{\circ} \mathrm{C}\right)$} & Morgan's Point & 0.93 & 0.99 & 0.92 & 0.99 \\
\hline & Eagle's Point & 1.27 & 0.99 & 1.26 & 0.99 \\
\hline & Bay Entrance & 0.91 & 0.99 & 0.86 & 0.99 \\
\hline \multirow[t]{2}{*}{ Surface velocity $\left(\mathrm{m} \mathrm{s}^{-1}\right)$} & Buoy B & 0.14 & 0.88 & 0.11 & 0.82 \\
\hline & Buoy F & 0.10 & 0.79 & 0.08 & 0.67 \\
\hline
\end{tabular}

a The value within parentheses indicates the mean depth of the sensor below the surface.
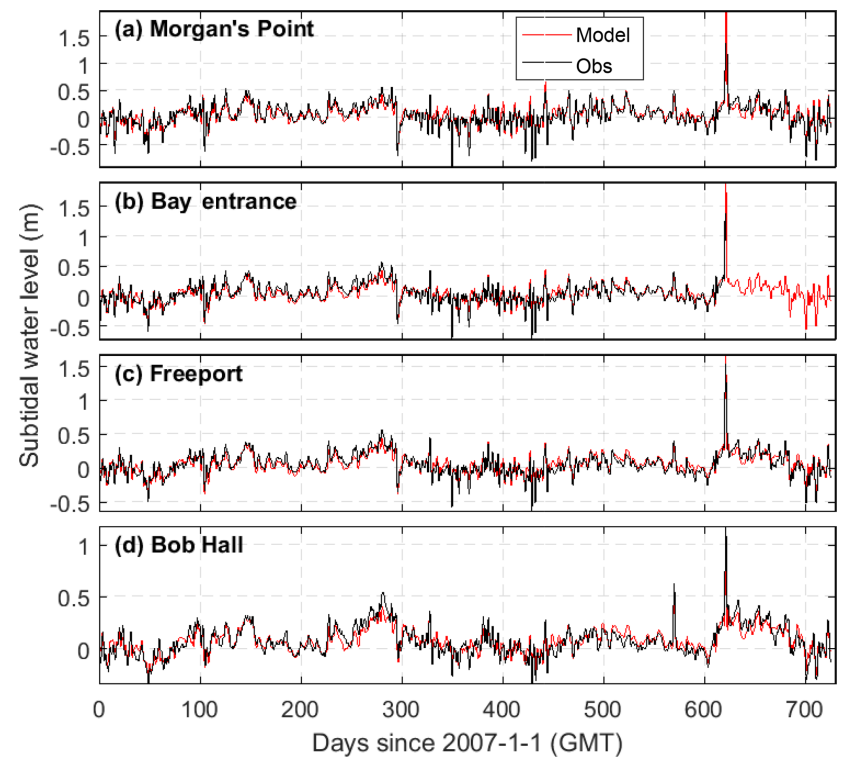

Figure 3. Subtidal surface elevation comparison between the model (red line) and observations (black line) at NOAA tidal gauge stations (see Fig. 2 for their locations).

of low-salinity water from neighboring estuaries, such as the nearby Sabine-Neches River, Atchafalaya River, and Mississippi River. Successful simulation of salinity at the bay mouth requires an accurate simulation of not only the baywide transport, but also the longshore transport. Errors in the modeled salinity at the bay mouth can propagate to the upper bay. For example, salinity during days $60-100$ is overestimated at the mouth (station BOLI) and this error propagated into the middle bay station (station MIDG) (Fig. 4). Discrepancies as large as $10 \mathrm{psu}$ are not likely caused by inaccurate discharge from the Trinity River, as this river has a very limited influence on the salinity on the shelf (further discussed in Sect. 4.3). Unfortunately, with no data available for the vertical salinity profile, the model performance for vertical mass transport cannot be evaluated. However, accurate simulation of the observed salinity at the mid-bay station provides alternative evidence supporting the model's validity in horizontal mass transport and salt intrusion.

The model also captures the sharp change in salinity during Hurricane Ike (around day 620). The salinity at the upper bay (Fig. 4b) decreased from 26 psu to 0 within $2 \mathrm{~d}$, which was caused by a pulse of freshwater discharge from Lake Houston (see reservoir storage at USGS 08072000). In addition, the model reproduces the spatial difference well in the amplitude of the tidal signal in salinity. Salinity in Trinity Bay (Fig. 4a) shows a very weak tidal signal, while salinity at the bay mouth (Fig. 4d) has a much stronger tidal signal. Galveston Bay, in general, has micro-tidal ranges with a mean tidal range of $0.3 \mathrm{~m}$ at the mid-bay station (Eagle Point in Fig. 2). The tidal signal, however, becomes stronger at the narrow bay mouth $(2.5 \mathrm{~km}$ wide), with the tidal current being as strong as $1 \mathrm{~m} \mathrm{~s}^{-1}$ (see station g06010 at http://pong.tamu.edu/tabswebsite/, last access: 7 November 2019).

The modeled salinity was also compared to the observed salinity structure over the Texas-Louisiana shelf using the 


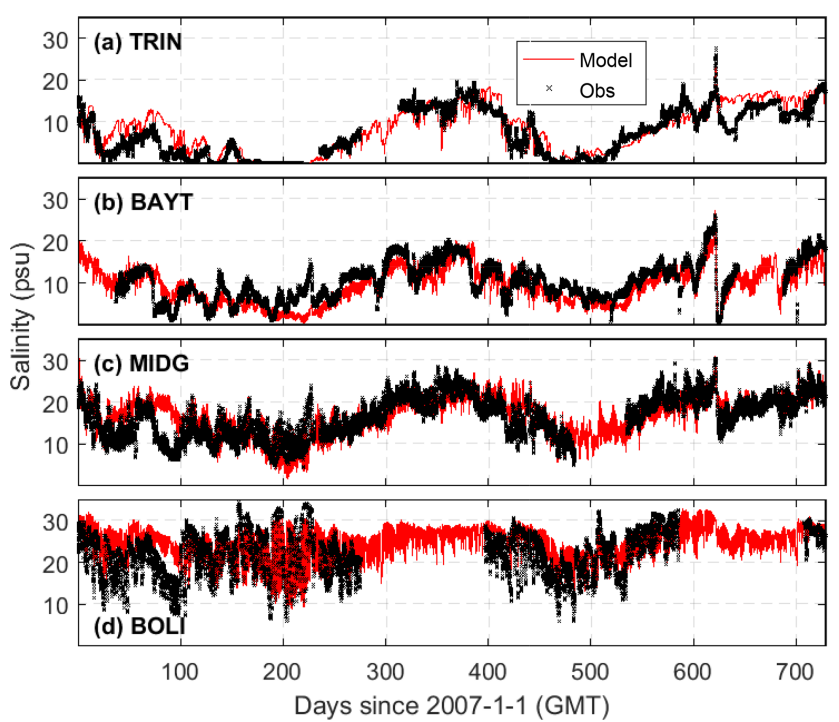

Figure 4. Salinity comparison between the model (red line) and observations (black cross) at four TWDB stations (see Fig. 2 for their locations).

data from a shelf-wide summer survey in July 2008 as an example (Fig. 5). Both the horizontal and vertical structures of salinity on the shelf are well reproduced by the model, with an MAE over 65 stations of 1 and 2 psu for the surface and bottom salinity, respectively. Data and the model consistently show a relatively shallow halocline at section A (west of Mississippi Delta) and a deeper halocline at section F (off Atchafalaya Bay). The upper layer off Atchafalaya Bay was nearly well mixed, which is also reproduced by the model, although the model somewhat underestimates the bottom salinity at section F. In addition, the model also shows that there was little tidal variability of the vertical salinity profile on the shelf (e.g., stations F4 and A7 in Fig. 5), which can be attributed to the small tidal range in the northern GoM.

\subsection{Temperature}

The model reproduces the observed temperatures well at three NOAA stations located from the Galveston Bay mouth to the upper bay (Fig. 6). Both the seasonal and diurnal cycles are well captured, with MAEs of about $1^{\circ} \mathrm{C}$ and model skills of 0.99. Even within a relatively small region inside Galveston Bay, temperature can vary significantly. During days 300-350, for example, large fluctuations in temperature occurred at the mid-bay station (Fig. 6b), while the fluctuations were smaller at the bay entrance (Fig. 6a) and the upper bay (Fig. 6c). These spatiotemporal variations are reproduced well by the model, demonstrating not only the good performance of the model, but also the reliability of the atmospheric forcing data.

The model performance in reproducing temperature over the Texas-Louisiana shelf was further examined with satel- lite data for sea surface temperature (SST). Seasonality of the SST extracted from MODIS over the northern GoM is overall reproduced well (Fig. 7). It is worth noting that the model also reproduces the relatively low temperatures on the southern Texas coast during summer, which is a wellknown upwelling zone during the summertime when upcoast (from Texas toward Louisiana) winds drive an offshore surface transport (Zavala-Hidalgo et al., 2003).

\subsection{Shelf current}

The shelf current plays a key role in transporting low-salinity water originating from MAR, and it can be affected by not only the wind field, but also the mesoscale eddies in the northern GoM. One of the important features of the TexasLouisiana shelf is the quasi-annual pattern of the shelf current, which is predominantly westward most of the time except during summer (Cochrane and Kelly, 1986; Li et al., 1997; Cho et al., 1998). The prominent downcoast shelf current is driven by along-shelf wind and enhanced by the MAR discharge (Oey, 1995; Li et al., 1997; Nowlin et al., 2005). Under summer wind that usually has an upcoast component, the nearshore current is reversed to the upcoast direction $(\mathrm{Li}$ et al., 1997). Such seasonality also occurred during 20072008. The model reproduces the observed subtidal component of the surface longshore current at two TABS buoy stations outside Galveston Bay, buoy B ( $\sim 20 \mathrm{~km}$ offshore) and buoy F ( $\sim 80 \mathrm{~km}$ offshore) (Fig. 8), with MAEs of $8-$ $14 \mathrm{~cm} \mathrm{~s}^{-1}$ and model skills of $0.67-0.88$ (Table 1 ).

\section{Remote influence of the MAR discharge}

The conditions in Texas coastal waters are impacted by several remote sources, including mesoscale eddies (Oey et al., 2005; Ohlmann and Niiler, 2005), longshore transport of low-salinity water from major rivers (Li et al., 1997; Nowlin et al., 2005), and Ekman transport induced by longshore wind and the resulting upwelling-downwelling ( $\mathrm{Li}$ et al., 1997; Zhang et al., 2012). Here, based on the realistic model results and numerical experiments, we discuss the remote influence of major river discharge and shelf dynamics on the longshore transport, salinity, stratification, and vertical mixing at the Texas coast, as well as the water exchange between the coastal ocean and local coastal system.

\subsection{Variation in shelf current and salinity}

The strength and direction of the shelf current are sensitive to the wind field. Comparison of the model results on day 150 (31 May 2007) and day 160 (10 June 2007) clearly shows the different distribution of lower-salinity water along the coast in response to wind field and the resulting shelf current (Fig. 9). The river discharge differences between these two days are negligible, and thus the differences in lowersalinity water distribution can be mainly attributed to the dif- 

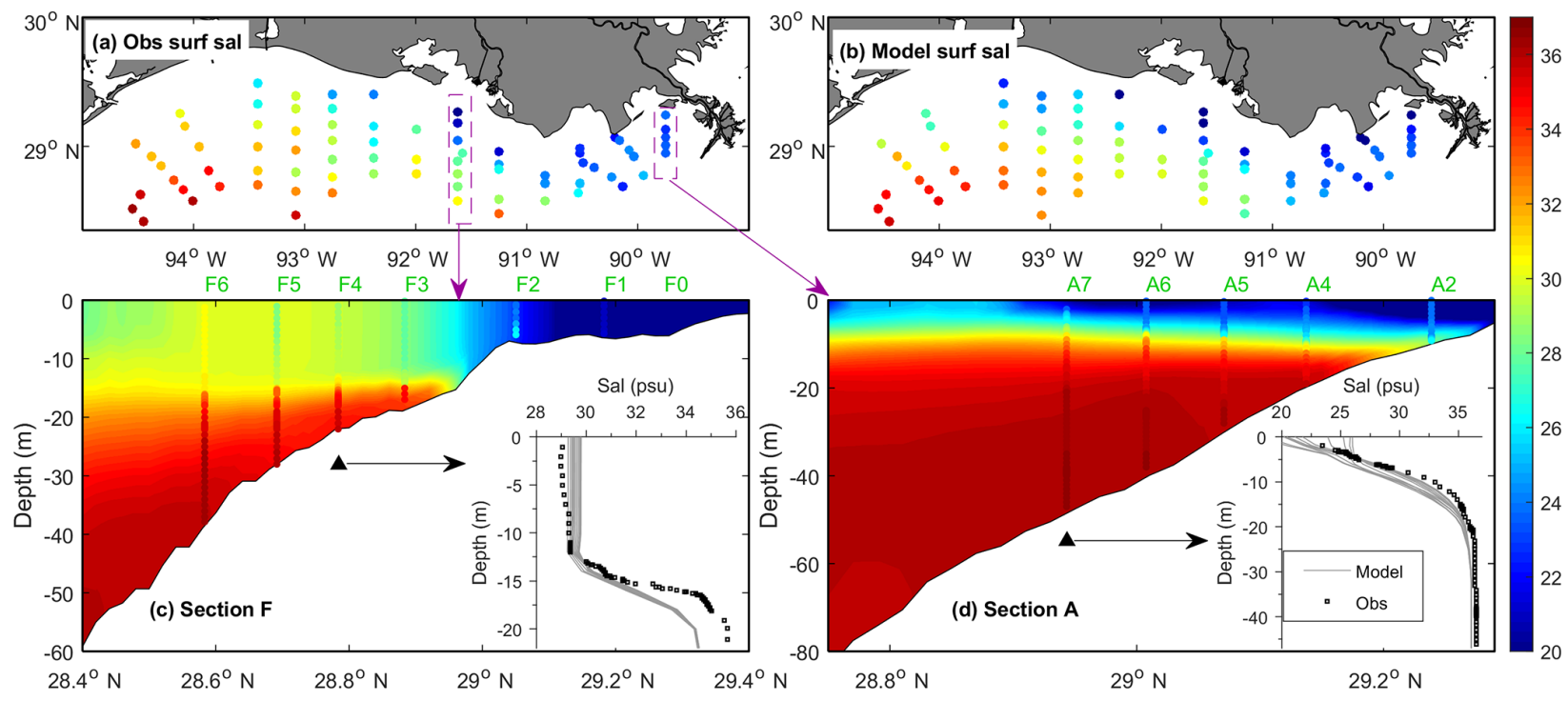

Figure 5. Salinity distribution at the Texas-Louisiana shelf from the shelf-wide survey on 22-27 July 2018: comparison of (a) observed and (b) modeled surface salinity and of the vertical profiles at two cross-shelf sections, (c) F and (d) A. In (c) and (d), the colored dots indicate observed salinity, while the filled colors indicate modeled salinity, and the insets compare the vertical profiles of salinity at the selected stations of F4 and A7, respectively. The grey lines in the insets show the 12 modeled profiles over $1 \mathrm{~d}$ (observation time $\pm 0.5 \mathrm{~d}$ ).
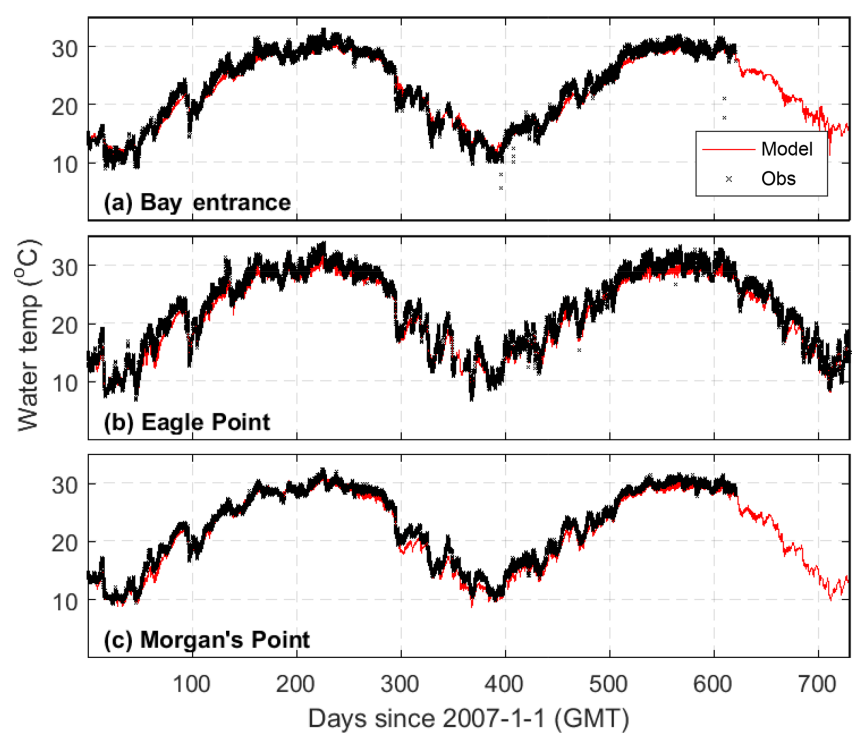

Figure 6. Temperature comparison between the model (red line) and observations (black line) at three NOAA stations (see Fig. 2 for their locations).

ferences in shelf current. Day 150 was characterized by a significant downcoast shelf current in the inner shelf, with a current speed exceeding $0.5 \mathrm{~m} \mathrm{~s}^{-1}$, while day 160 was characterized by a rather weak shelf current with a speed of less than $0.1 \mathrm{~m} \mathrm{~s}^{-1}$. The pattern of the surface residual current is related to the wind field. On day 150 , a downcoast component of the wind induced an onshore Ekman transport, which in turn resulted in a downcoast geostrophic flow ( $\mathrm{Li}$ et al.,
1997). This downcoast flow transported low-salinity water from MAR toward Texas while constraining it to a narrow band against the shoreline (Fig. 9e). Under a weak or upcoast shelf current, in contrast, this constraining was weakened, leading to the offshore displacement of low-salinity water (Fig. 9f). As a result, salinity on the Texas inner shelf was higher on day 160 than on day 150 .

Regulated by the shelf current, salinity distribution over the shelf exhibits evident seasonality. The model results show that a narrow band of lower-salinity water persisted from Louisiana to the western Texas inner shelf during JanuaryMay 2008 (Fig. 10). The salinity at the Galveston Bay mouth decreased by about 10 psu from January to May, which can be attributed to the increasing Mississippi discharge from January to May in 2008 (Mississippi discharge data at https:// waterdata.usgs.gov/usa/nwis/uv?site_no $=07374000$, last access: 7 November 2019). Starting from June 2008, the salinity along the western Texas shelf gradually increased as higher-salinity water from the southwestern boundary moved upcoast. The salinity at the Galveston Bay mouth increased from less than 20 psu in June to $>30$ psu in August (Fig. 10), about the same magnitude of salinity change from January to May. It suggests that the influence of the seasonally varying shelf circulation on salinity at the Texas coast is comparable to that of the seasonal variation in the MAR discharge.

\subsection{Influence of the MAR discharge on shelf transport and salinity}

Longshore transport plays a key role in redistributing freshwater from the estuarine bays along the shelf. The results 


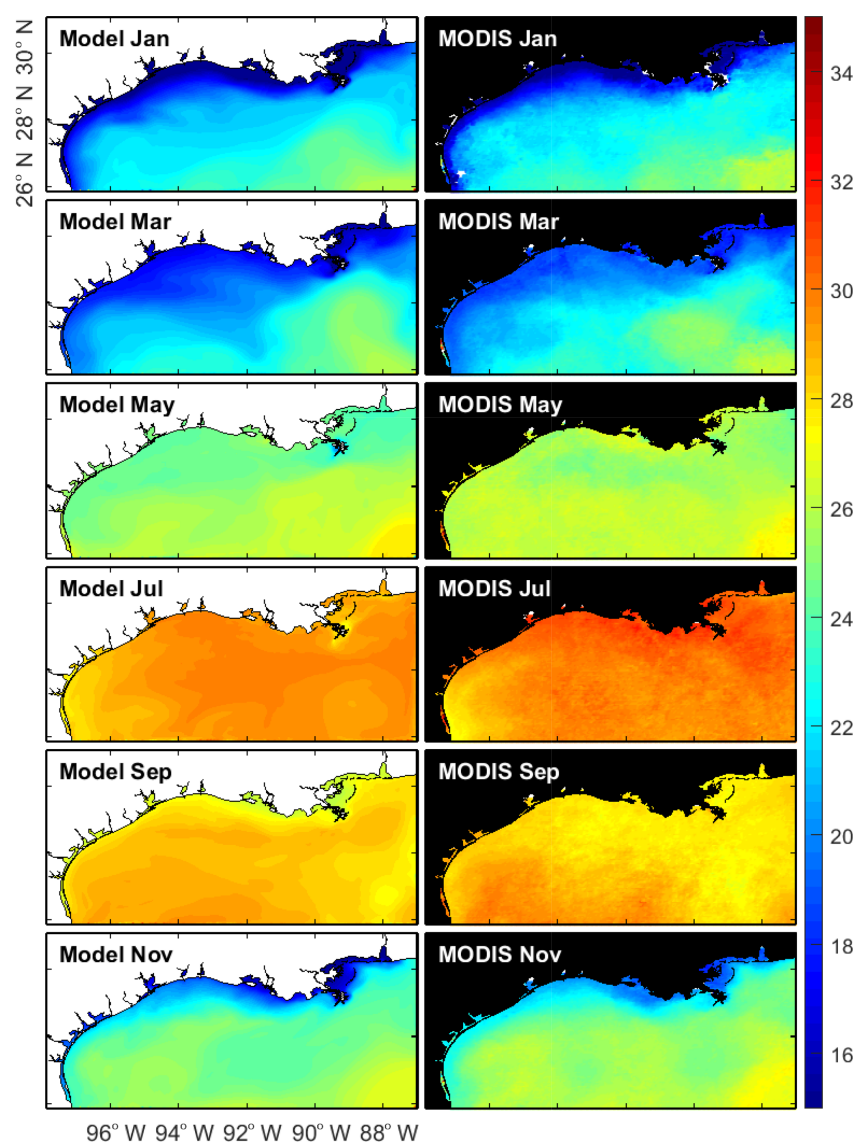

Figure 7. Temperature comparison (monthly average) between the model (left panels) and MODIS satellite data (right panels) for selected months in 2008.

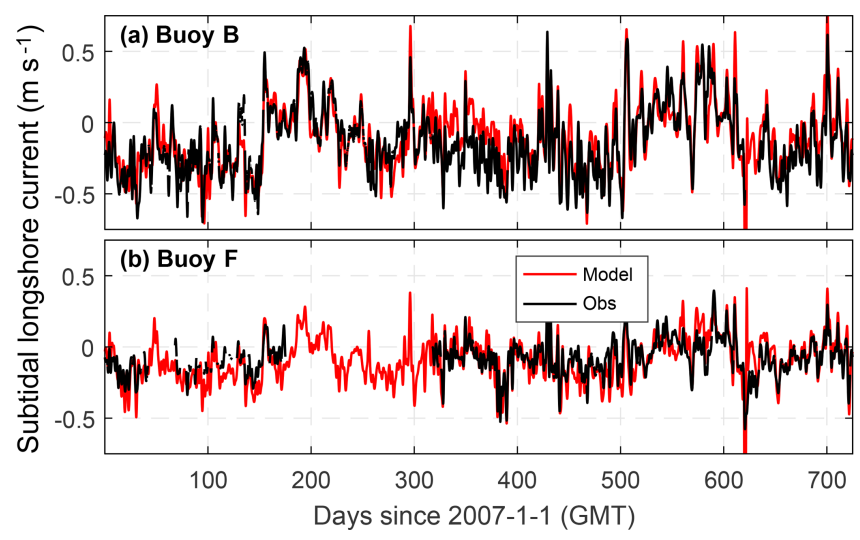

Figure 8. Comparison of the subtidal east-west surface shelf current between the model (red line) and observations (black line) at two TABS buoys (see Fig. 2 for their locations).

from three numerical experiments show that, under the January wind, the downcoast longshore transport among four selected cross-shelf sections varies little. The longshore transport is enhanced by the MAR discharge (long-term mean) by $10 \%-14 \%\left(\sim 80000 \mathrm{~m}^{3} \mathrm{~s}^{-1}\right)$, about 4 times the long-term mean river discharge from MAR $\left(\sim 22000 \mathrm{~m}^{3} \mathrm{~s}^{-1}\right)$ (Fig. 11). The transport, however, is greatly reduced under the July wind and it decreases downcoast, with the magnitude being 1 order smaller on the Texas shelf compared to that under the January wind. The difference in longshore transport is related to the shelf circulations, which exhibit distinctly different patterns under different wind conditions (Fig. S3). Under the January wind, the surface shelf current flows downcoast, while under the July wind, it is weak and mainly in a direction normal to the coastline, resulting in a much smaller longshore transport.

The influence of the MAR discharge on shelf salinity also depends on the wind condition and the resulting shelf current. Surface salinity maps averaged over days $250-300$ show distinctly different spatial patterns of the lower-salinity water under different wind conditions (Fig. 12). The patterns are similar to the results from the 2007-2008 realistic run (Fig. 10). Under the winter wind, lower-salinity water is trapped nearshore by the shelf current, forming a narrow band along the coast. Under the summer wind, on the other hand, water on the Texas shelf is replenished by saltier water originating from the southwest, leading to a tongue-shaped saltier-water intrusion toward the lower-salinity water over the Louisiana shelf. Consequently, salinity is higher on the Texas shelf and lower on the Louisiana shelf when compared to that under the winter wind.

\subsection{Influence of the MAR discharge on Texas coast: salinity, stratification, and mixing}

Numerical experiments reveal different time and spatial scales with which the surface salinity in Texas coastal water responds to the MAR discharge (Fig. 13). At the Galveston Bay mouth, the salinity begins to decrease from about day 25 in response to the MAR discharge and continues to decrease until around day 100 when it reaches a quasi-steady state. The MAR discharge (long-term mean) reduces the salinity by about 10 psu under the January wind but only by 5-6 psu under the July wind. Further south at the Port Aransas mouth, the response time doubles to about $50 \mathrm{~d}$, with the MAR discharge reducing the salinity by about 6 psu under the January wind. Salinity changes little in response to discharges from Galveston Bay and the MAR discharge under the July wind. As the influence from Galveston Bay is very limited at the Aransas Bay mouth even under a downcoast wind, it is reasonable to assume the influence will be even smaller under an upcoast wind.

Vertical profiles of salinity along a section from the Trinity Bay, along the Houston Ship Channel and the adjoining shelf, show that the MAR discharge increases salinity stratification on the shelf (Fig. 14). The lower-salinity water along the coastline increases the cross-shelf baroclinic pressure gradient, leading to a stronger stratification. There is a distinctive difference between Jan-GAM and Jul-GAM. A stronger stratification on the inner shelf appears under the July wind, 


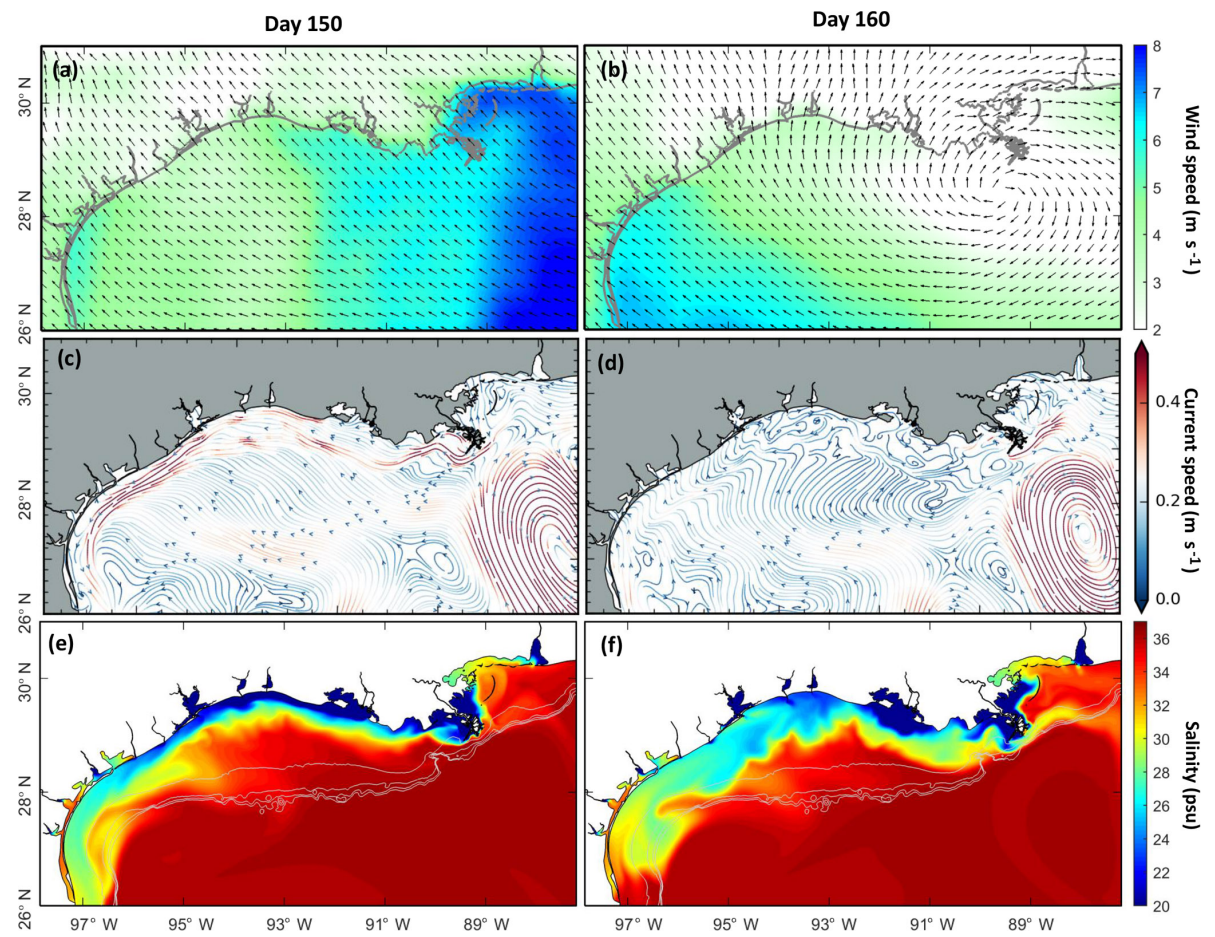

Figure 9. Comparison of the observed wind field and the modeled surface residual current and surface salinity on day 150 (31 May 2007) and day 160 (10 June 2017). The filled colors indicate the daily mean wind speed (a, b), the speed of the residual current (c, d), and salinity (e, f).

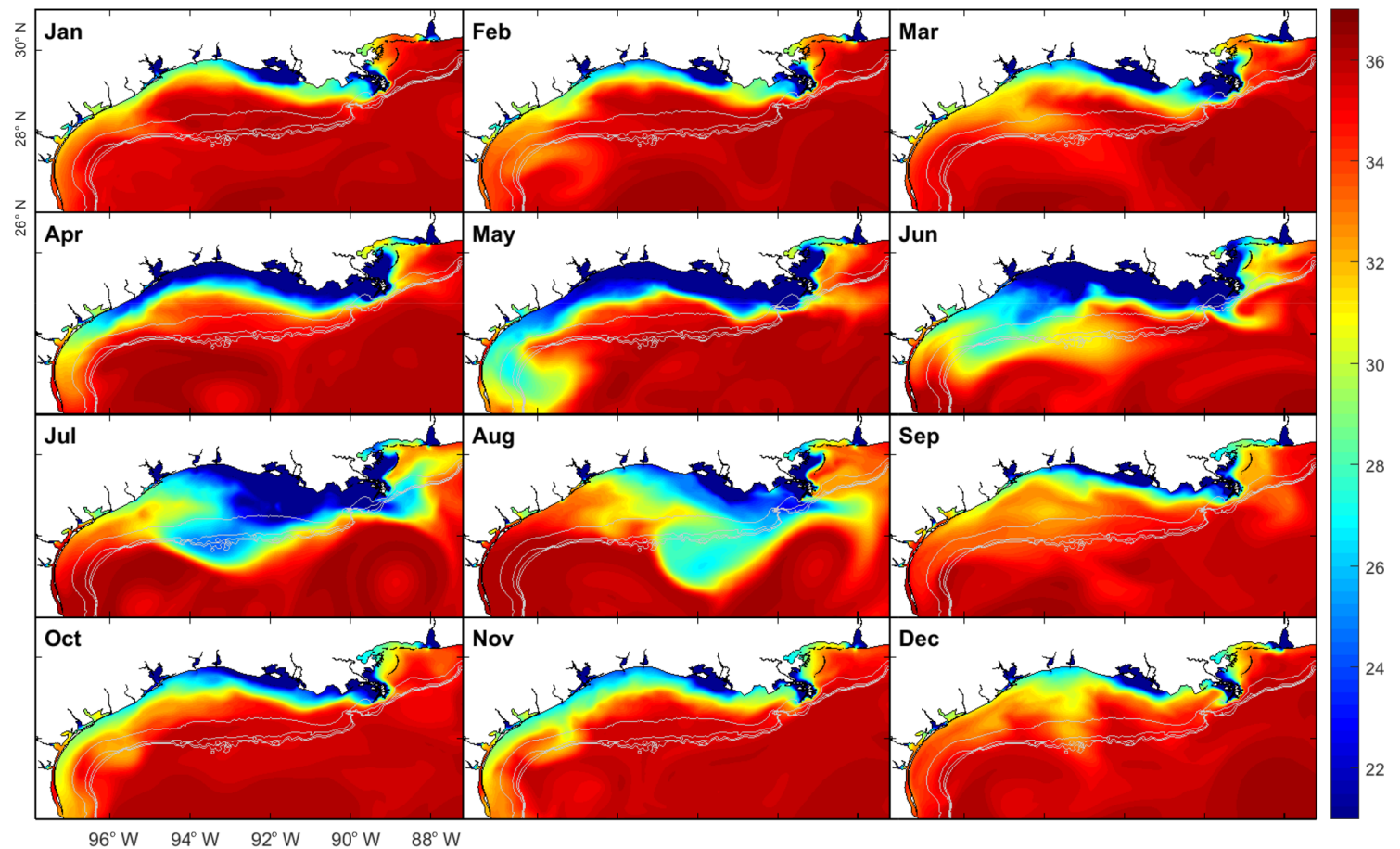

Figure 10. The modeled monthly mean surface salinity in 2008, with the grey contour lines denoting depth contours of 50, 100, 150 , and $200 \mathrm{~m}$. 

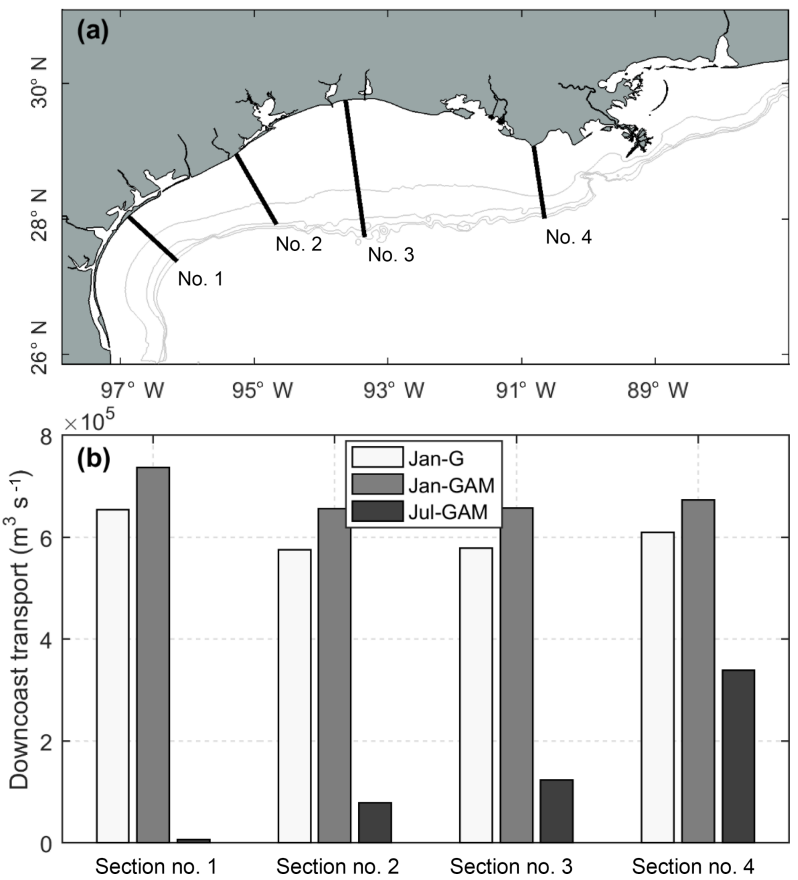

Figure 11. Downcoast longshore transport at four selected crossshelf sections for three numerical experiments with constant longterm mean river discharges: river discharges into Galveston Bay only with January 2018 wind (Jan-G) and the MAR discharge as well as discharges into Galveston Bay with January 2018 wind (JanGAM) or July 2018 wind (Jul-GAM).

with the bottom-surface salinity difference as large as 4 psu. Vertical mixing on the inner Texas shelf is weakened due to the MAR discharge, particularly under the July wind. The vertical diffusivities are 1 or 2 orders of magnitude smaller than those under the January wind. Under the July wind, the stratification along the ship channel becomes stronger, probably because of higher salinity near the bay mouth and/or a weaker wind in July with a mean speed of $4.79 \mathrm{~m} \mathrm{~s}^{-1}$ relative to a mean speed of $6.88 \mathrm{~m} \mathrm{~s}^{-1}$ in January (Fig. S1). Higher salinity near the mouth induces a stronger horizontal salinity gradient, leading to stronger circulation and stratification.

\subsection{Influence of the MAR discharge on estuarine-coastal exchange}

Salinity change due to remote river input and a shift in the wind field affects the estuarine dynamics, such as estuarine circulation, salt flux, and estuarine-coastal exchange. We examined the change in exchange flow and salinity at the Galveston Bay mouth due to remote river influence and a different shelf current. Following Lerzak et al. (2006), we calculated the tidally averaged and cross-sectionally varying components $\left(u_{\mathrm{e}}\right.$ and $\left.S_{\mathrm{e}}\right)$ from the along-channel velocity $u$ and salinity $S$. From the vertical profiles of $u_{\mathrm{e}}$ and $S_{\mathrm{e}}$ at the deepest part between the two jetties at the bay mouth, it is evident that in the lower layer $u_{\mathrm{e}}$ is strongest (maximum of $6 \mathrm{~cm} \mathrm{~s}^{-1}$ )

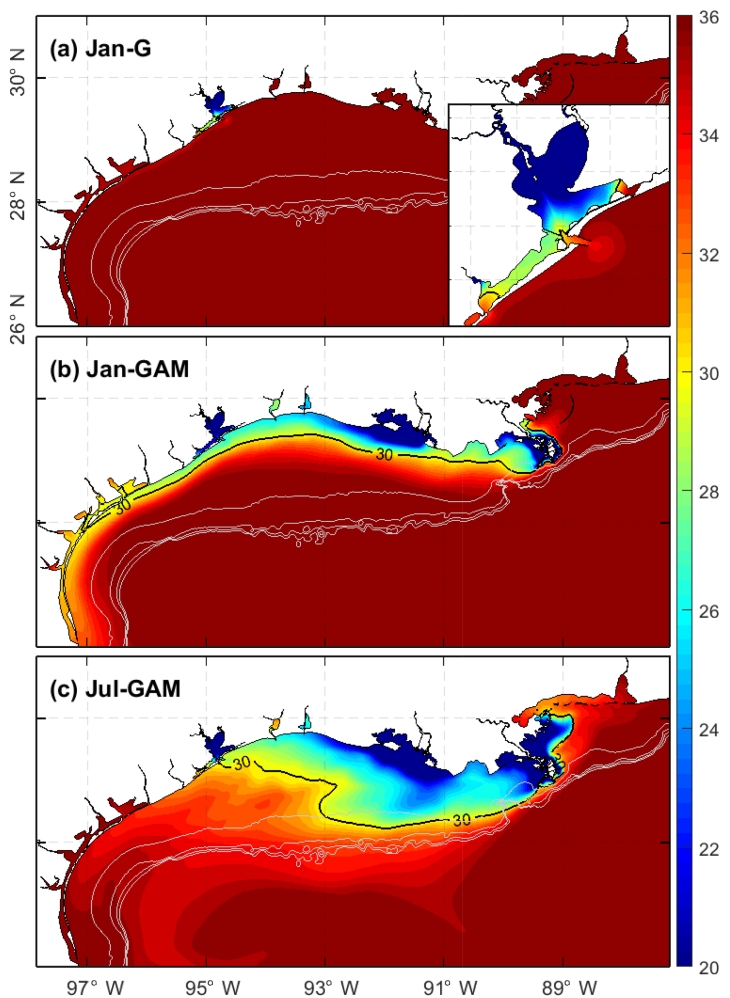

Figure 12. Surface salinity distributions averaged over days 250 300 from three numerical experiments. Grey contour lines denote depth contours for 50,100, 150, and $200 \mathrm{~m}$.

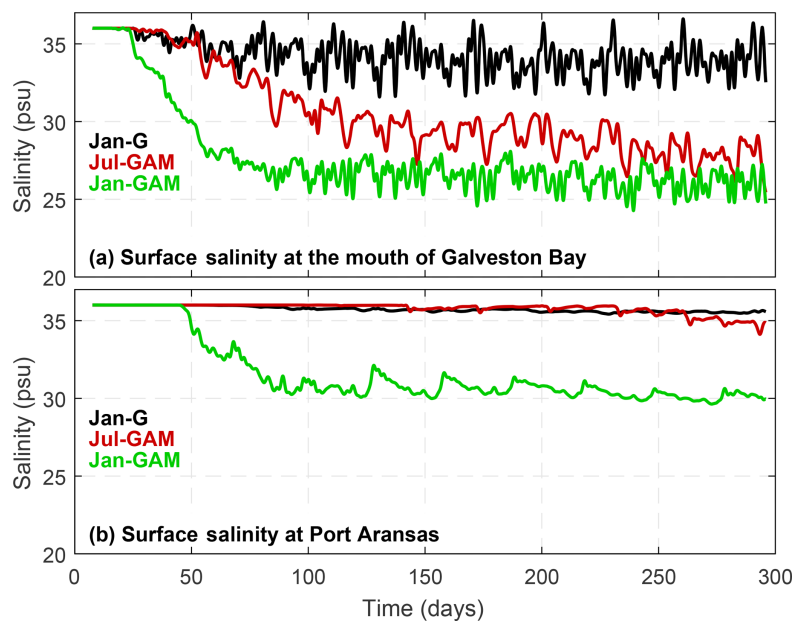

Figure 13. Subtidal surface salinity at the mouth of (a) Galveston Bay and (b) Aransas Bay for three numerical experiments.

and $S_{\mathrm{e}}$ is largest (maximum of $0.95 \mathrm{psu}$ ) for the case Jan-G, indicating the strongest exchange flow (i.e., estuarine circulation) compared to the other two cases with the MAR discharge (Fig. 15). In contrast, the case Jan-GAM shows the weakest bottom $u_{\mathrm{e}}$ (maximum of $4 \mathrm{~cm} \mathrm{~s}^{-1}$ ) and the smallest bottom $S_{\mathrm{e}}$ (maximum of $0.60 \mathrm{psu}$ ). The MAR discharge 

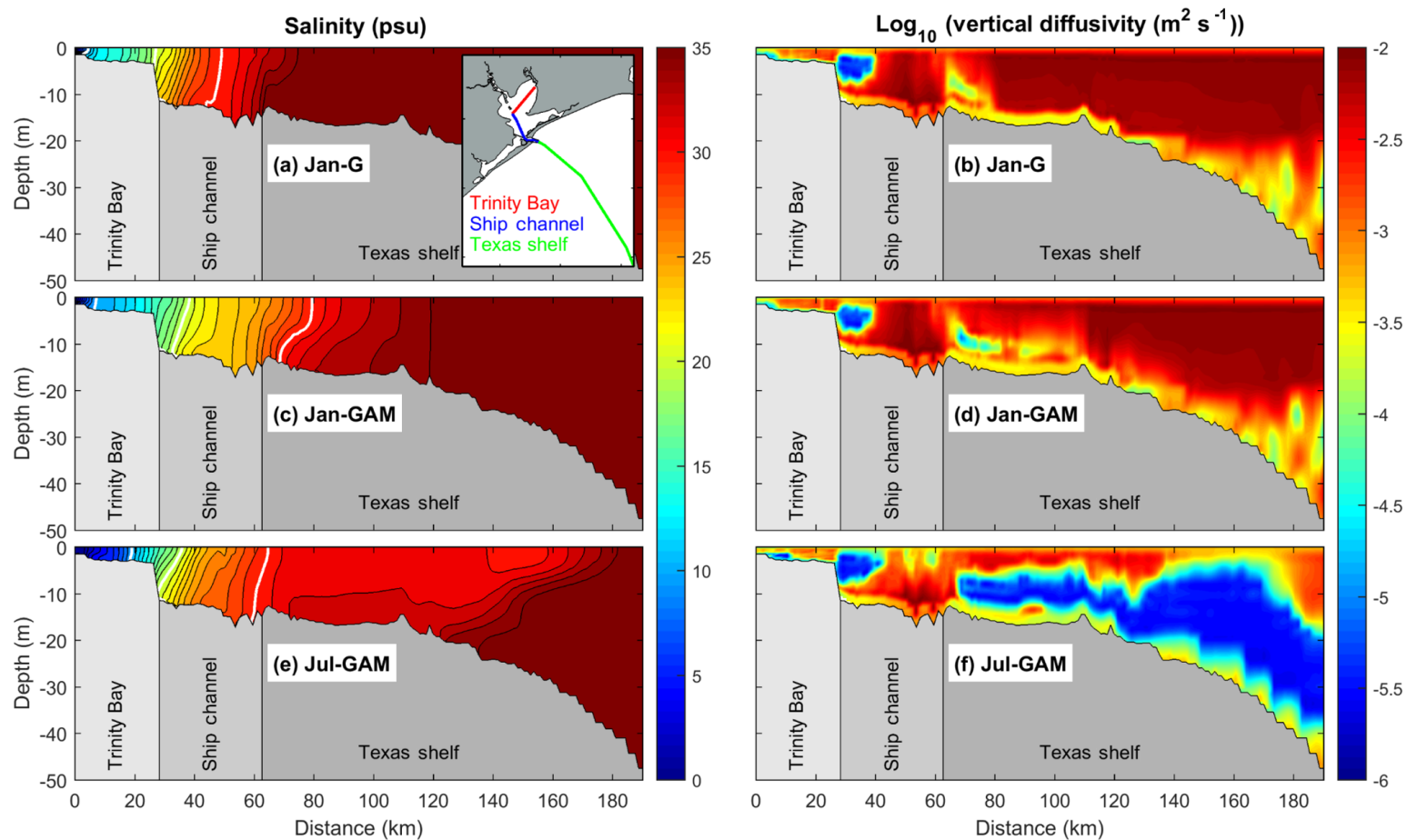

Figure 14. Salinity (a, c, e) and vertical diffusivity (b, d, f) averaged over days 250-300 from three numerical experiments for the section through Trinity Bay, the Galveston Bay ship channel, and the Texas shelf: see the inset in (a) for the section location. In (a), the bold white lines denote salinity contours of 10,20 , and 30 psu.
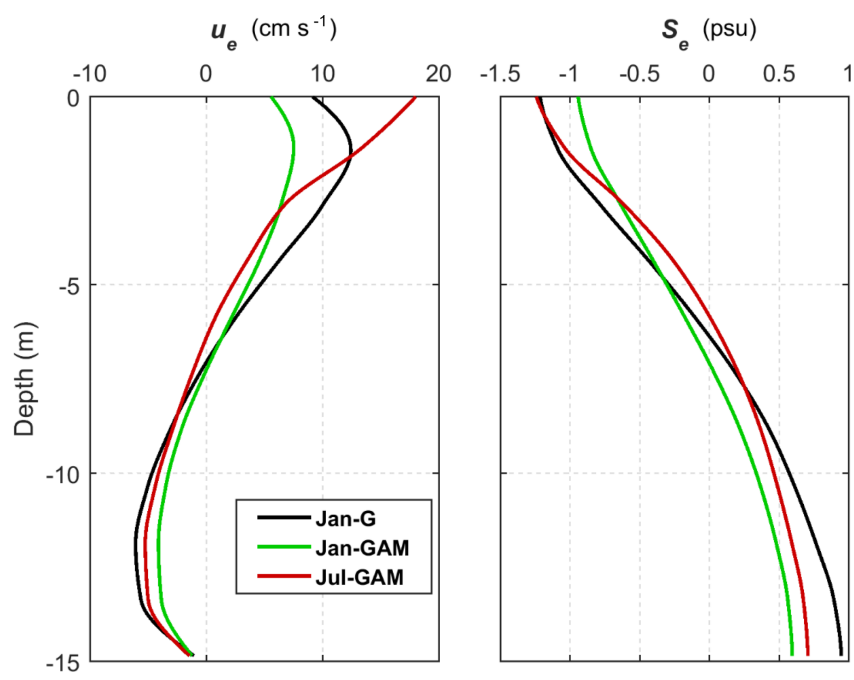

Figure 15. Vertical profiles of exchange flow $\left(u_{\mathrm{e}}\right)$ and salinity $\left(S_{\mathrm{e}}\right)$ at the deepest part of the Galveston Bay mouth averaged over days 250-300 for three numerical experiments.

under the January wind condition decreases the salinity at the bay mouth the most and results in the weakest horizontal salinity gradient and exchange flow.

The influence of the MAR discharge on the dynamics of Galveston Bay was further examined with total exchange flow (TEF) using the isohaline framework method proposed by MacCready (2011), which was found to be a precise way to quantify landward salt transport (Chen et al., 2012). In this method, the tidally averaged volume flux of water with salinity greater than $s$ is defined as

$Q(s)=\left\langle\int_{A_{\mathrm{s}}} u \mathrm{~d} A\right\rangle$,

where $A_{s}$ is the tidally varying portion of the cross section with salinity greater than $s$. In our case, we calculated $Q(s)$ for the salinity bins from 0 to 35 psu with an interval of $0.5 \mathrm{psu}$. The volume flux in a specific salinity class is defined as

$-\frac{\partial Q}{\partial s}=-\lim _{\delta s \rightarrow 0} \frac{Q(s+\delta s / 2)-Q(s-\delta s / 2)}{\delta s}$,

where the minus sign indicates that a positive value of $-\partial Q / \partial s$ corresponds to inflow for a given salinity class. The total exchange flow $\left(Q_{\text {in }}\right)$, the flux of water into the estuary due to all tidal and subtidal processes, is then calculated as

$\left.Q_{\text {in }} \equiv \int \frac{-\partial Q}{\partial s}\right|_{\text {in }} \mathrm{d} s$.

The resulting salt flux into the estuary $\left(F_{\text {in }}\right)$ is given by

$F_{\text {in }}=\left.\int s\left(-\frac{\partial Q}{\partial s}\right)\right|_{\text {in }} \mathrm{d} s$, 
Table 2. Total exchange flow $\left(Q_{\text {in }}\right)$ and the resulting salt flux $\left(F_{\text {in }}\right)$ at the Galveston Bay mouth, as well as the mean residence time of the bay $\left(T_{\text {res }}\right)$ based on the isohaline method in MacCready (2011).

\begin{tabular}{lrrrr}
\hline Case ID $^{\mathrm{a}}$ & $\begin{array}{r}Q_{\text {in }} \\
\left(\mathrm{m}^{3} \mathrm{~s}^{-1}\right)\end{array}$ & $\begin{array}{r}F_{\text {in }} \\
\left(\mathrm{kg} \mathrm{salt} \mathrm{s}^{-1}\right)\end{array}$ & $\begin{array}{r}T_{\text {res }} \\
(\text { days })\end{array}$ & $\begin{array}{r}S_{\text {mean }}^{\mathrm{b}} \\
(\mathrm{psu})\end{array}$ \\
\hline Jan-G & $1.93 \times 10^{3}$ & $6.75 \times 10^{4}$ & 13.0 & 20 \\
\hline Jan-GAM & $1.46 \times 10^{3}$ & $3.47 \times 10^{4}$ & 16.0 & 13 \\
Jul-GAM & $1.80 \times 10^{3}$ & $5.30 \times 10^{4}$ & 13.1 & 16 \\
\hline
\end{tabular}

${ }^{a}$ See Fig. 11 for an explanation of idealized runs. ${ }^{b}$ Mean salinity

(volume-weighted average over days 250-300) inside the bay.

and the ratio of salt mass inside the estuary to the salt influx gives the mean residence time $\left(T_{\text {res }}\right)$ :

$T_{\text {res }}=\frac{\int s \mathrm{~d} V}{F_{\text {in }}}$,

where $V$ is the estuarine volume.

Table 2 lists the values of $Q_{\text {in }}, F_{\text {in }}$, and $T_{\text {res }}$ for three numerical experiments. For the exchange flow, $Q_{\text {in }}$ is largest for the case Jan-G and smallest for the case Jan-GAM. The MAR discharge under the January wind condition causes the largest decrease in salinity at the Galveston Bay mouth (Fig. 13a), effectively slowing down the water exchange between the bay and coastal ocean. The reduction in $Q_{\text {in }}$ caused by the remote discharge $\left(470 \mathrm{~m}^{3} \mathrm{~s}^{-1}=24 \%\right.$ reduction $)$ is 1.8 times the long-term mean river input into Galveston Bay $\left(259 \mathrm{~m}^{3} \mathrm{~s}^{-1}\right)$. Moreover, $F_{\text {in }}$ for the case Jan-GAM is about half of that in the case Jan-G. As a result, $T_{\text {res }}$ of the bay is largest in the case Jan-GAM, although the difference in $T_{\text {res }}$ is not as large as that in $F_{\text {in }}$ because the bay has the smallest salt mass in the case Jan-GAM (Table 2). This analysis also suggests that the exchange between the bay and coastal ocean is likely stronger during summer than during winter under the same river discharge condition.

\section{Summary}

An unstructured-grid hydrodynamic model with a hybrid vertical grid was developed and validated for water level, current velocity, salinity, and temperature for Galveston Bay as well as over the shelf in the northern GoM. The good model performance, particularly in terms of salinity (vertically and horizontally), is at least in part attributable to the inclusion of multiple river plumes along the coastline as well as the interaction between estuaries and the shelf. This model provides a good platform that can be used for other purposes in future studies. Its flexibility in the horizontal and vertical grids allows for refinement in any region of interest without a penalty in the time step (due to the semi-implicit scheme). For example, it would be relatively easy to adapt the model by refining the grid inside any target bay, e.g., Corpus Christi Bay.
The 2007-2008 model run reveals the seasonally varying influence of the MAR discharge on the Texas shelf. Three numerical experiments were carried out to examine the extent to which the major rivers in the region influence local coastal bay systems in Texas. The MAR discharge has a great influence on the salinity regime along the Texas coast and its influence depends on the wind-controlled shelf circulation. Winter wind drives a stronger downcoast longshore transport with its magnitude at least 1 order larger than that under summer wind. The MAR discharge (long-term mean) enhances the downcoast transport by $10 \%-14 \%$ under winter wind, and it lowers the salinity by up to $10 \mathrm{psu}$ at the mouth of Galveston Bay and 6 psu at the mouth of Port Aransas. Vertical mixing is also sensitive to wind forcing. Summer wind tends to displace low-salinity water further offshore, while the winter wind constrains the low-salinity water to a narrow band against the shoreline. As a result, the stratification is stronger and vertical mixing is weaker over the shelf during summer. The lower-salinity condition on the Texas shelf decreases the longitudinal salinity gradient at the bay mouth, leading to a weakened estuarine circulation and weaker salt exchange.

This study demonstrates the necessity of including the remote influence of the MAR discharge for modeling Texas coastal systems, particularly for processes associated with relatively long timescales (e.g., months). Receiving relatively small freshwater discharge and being limited by narrow outlets and small tidal ranges, the estuarine bay systems along the Texas coast, e.g., Galveston Bay, Aransas Bay, and Corpse Christi Bay, are characterized by relatively slow water exchange and long flushing times. In this study, we show that the exchange flow plays an important role for water renewal and that the exchange flow varies greatly depending on the wind field and the resulting shelf current. Modulation by the MAR discharge, when coupled with downcoast wind conditions, could have a great influence on the dynamics of estuaries along the Texas coast.

Data availability. All the observational data used for model validation are available online. Salinity data are extracted from TDWB (https://waterdatafortexas.org/coastal). Continuous monitoring data on temperature and water level are extracted from NOAA Tide and Current (https://tidesandcurrents.noaa.gov/). Surface buoy current data are extracted from TABS (http://pong.tamu.edu/tabswebsite/). Daily satellite data (4 km resolution) are extracted from https:// podaac.jpl.nasa.gov/. Shelf-wide summer survey data for 2008 are accessible at the National Oceanographic Data Center (NODC) with the accession number 0069471 (https://www.data.gov/). The model output is available upon request. All URLs in this section were last accessed on 7 November 2019.

Supplement. The supplement related to this article is available online at: https://doi.org/10.5194/os-15-951-2019-supplement. 
Author contributions. JD and KP led the effort for model development, data analysis, and preparation of the paper. JS, YJZ, FY, and $\mathrm{ZW}$ provided guidelines for the model configuration in terms of forcings and boundary conditions. XY assisted in the visualization of modeled and observed data. NNR provided the shelf-wide survey data for the model validation. All authors were involved in writing the paper.

Competing interests. The authors declare that they have no conflict of interest.

Acknowledgements. The numerical simulation was performed on the high-performance computer cluster at the College of William and Mary.

Financial support. This study was partially supported by the Texas Coastal Management Program, the Texas General Land Office, and NOAA through CMP contract no. 19-040-000-B074.

Review statement. This paper was edited by Eric J. M. Delhez and reviewed by Ivica Janeković and one anonymous referee.

\section{References}

Androulidakis, Y. S., Kourafalou, V. H., and Schiller, R. V.: Process studies on the evolution of the Mississippi River plume: Impact of topography, wind and discharge conditions, Cont. Shelf Res., 107, 33-49, https://doi.org/10.1016/j.csr.2015.07.014, 2015.

Barkan, R., McWilliams, J. C., Shchepetkin, A. F., Molemaker, M. J., Renault, L., Bracco, A., and Choi, J.: Submesoscale dynamics in the northern Gulf of Mexico. Part I: Regional and seasonal characterization, and the role of river outflow, J. Phys. Oceanogr., 47, 2325-2346, https://doi.org/10.1175/JPO-D-17-0035.1, 2017.

Bauer, R. T.: Reproductive ecology of a protandric simultaneous hermaphrodite, the Shrimp Lysmata Wurdemanni (Decapoda: Caridea: Hippolytidae), J. Crustac. Biol., 22, 742-749, https://doi.org/10.1163/20021975-99990288, 2002.

Bianchi, T. S., DiMarco, S. F., Cowan, J. H., Hetland, R. D., Chapman, P., Day, J. W., and Allison, M. A.: The science of hypoxia in the northern Gulf of Mexico: A review, Sci. Total Environ., 408, 1471-1484, https://doi.org/10.1016/j.scitotenv.2009.11.047, 2010.

Bracco, A., Choi, J., Joshi, K., Luo, H., and McWilliams, J. C.: Submesoscale currents in the northern Gulf of Mexico: Deep phenomena and dispersion over the continental slope, Ocean Model., 101, 43-58, https://doi.org/10.1016/j.ocemod.2016.03.002, 2016.

Carrere, L., Lyard, F., Cancet, M., and Guillot, A.: FES 2014, a new tidal model on the global ocean with enhanced accuracy in shallow seas and in the Arctic region, in: Abstracts of the EGU General Assembly 2015, Vienna, Austria, 12-17 April 2015, available at: http://adsabs.harvard.edu/abs/2015EGUGA..17.5481C (last access: 7 November 2019), 2015.
Chen, C., Beardsley, R. C., and Cowles, G.: An unstructured grid, finite-volume coastal ocean model (FVCOM) system, Oceanography, 19, 78-89, https://doi.org/10.5670/oceanog.2006.92, 2006.

Chen, S.-N., Geyer, W. R., Ralston, D. K., and Lerczak, J. A.: Estuarine exchange flow quantified with isohaline coordinates: Contrasting long and short estuaries, J. Phys. Oceanogr., 42, 748763, https://doi.org/10.1175/JPO-D-11-086.1, 2012.

Cho, K., Reid, R. O., and Nowlin Jr., W. D.: Objectively mapped stream function fields on the Texas-Louisiana shelf based on 32 months of moored current meter data, J. Geophys. Res., 103, 10377-10390, https://doi.org/10.1029/98JC00099, 1998.

Chu, P. P., Ivanov, L. M., and Melnichenko, O. V.: Fall-winter current reversals on the Texas-Louisiana continental shelf, J. Phys. Oceanogr., 35, 902-910, https://doi.org/10.1175/JPO2703.1, 2005.

Cochrane, J. D. and Kelly, F. J.: Low-frequency circulation on the Texas-Louisiana continental shelf, J. Geophys. Res., 91, 1064510659, https://doi.org/10.1029/JC091iC09p10645, 1986.

DiMarco, S. F., Howard, M. K., and Reid, R. O.: Seasonal variation of wind-driven diurnal current cycling on the TexasLouisiana continental shelf, Geophys. Res. Lett., 27, 1017-1020, https://doi.org/10.1029/1999GL010491, 2000.

Du, J., Park, K., Shen, J., Dzwonkowski, B., Yu, X., and Yoon, B. I.: Role of baroclinic processes on flushing characteristics in a highly stratified estuarine system, Mobile Bay, Alabama, J. Geophys. Res.-Oceans, 123, 4518-4537, https://doi.org/10.1029/2018JC013855, 2018a.

Du, J., Shen, J., Zhang, Y. J., Ye, F., Liu, Z., Wang, Z., Wang, Y. P., Yu, X., Sisson, M., and Wang, H. V.: Tidal response to sea-level rise in different types of estuaries: The importance of length, bathymetry, and geometry, Geophys. Res. Lett., 45, 227235, https://doi.org/10.1002/2017GL075963, 2018 b.

Du, J. and Park, K.: Estuarine salinity recovery from an extreme precipitation event: Hurricane Harvey in Galveston Bay, Sci. Total Environ., 670, 1049-1059, https://doi.org/10.1016/j.scitotenv.2019.03.265, 2019a.

Dukhovskoy, D. S., Morey, S. L., Martin, P. J., O’Brien, J. J., and Cooper, C.: Application of a vanishing, quasi-sigma, vertical coordinate for simulation of high-speed, deep currents over the Sigsbee Escarpment in the Gulf of Mexico, Ocean Model., 28, 250-265, https://doi.org/10.1016/j.ocemod.2009.02.009, 2009.

Dzwonkowski, B., Park, K., and Collini, R.: The coupled estuarineshelf response of a river-dominated system during the transition from low to high discharge, J. Geophys. Res.-Oceans, 120, 61456163, https://doi.org/10.1002/2015JC010714, 2015

Fennel, K., Hetland, R., Feng, Y., and DiMarco, S.: A coupled physical-biological model of the Northern Gulf of Mexico shelf: model description, validation and analysis of phytoplankton variability, Biogeosciences, 8, 1881-1899, https://doi.org/10.5194/bg-8-1881-2011, 2011.

Gierach, M. M., Vazquez-Cuervo, J., Lee, T., and Tsontos, V. M.: Aquarius and SMOS detect effects of an extreme Mississippi River flooding event in the Gulf of Mexico, Geophys. Res. Lett., 40, 5188-5193, https://doi.org/10.1002/grl.50995, 2013.

Hetland, R. D. and DiMarco, S. F.: How does the character of oxygen demand control the structure of hypoxia on the Texas-Louisiana continental shelf?, J. Marine Syst., 70, 49-62, https://doi.org/10.1016/j.jmarsys.2007.03.002, 2008. 
Huang, W. J., Cai, W.-J., Castelao, R. M., Wang, Y., and Lohrenz, S. E.: Effects of a wind-driven cross-shelf large river plume on biological production and $\mathrm{CO}_{2}$ uptake on the Gulf of Mexico during spring, Limnol. Oceanogr., 58, 1727-1735, https://doi.org/10.4319/lo.2013.58.5.1727, 2013.

Justić, D., Rabalais, N. N., and Turner, R. E.: Effects of climate change on hypoxia in coastal waters: A doubled $\mathrm{CO}_{2}$ scenario for the northern Gulf of Mexico, Limnol. Oceanogr., 41, 9921003, https://doi.org/10.4319/1o.1996.41.5.0992, 1996.

Kantha, L. H. and Clayson, C. A.: An improved mixed layer model for geophysical applications, J. Geophys. Res., 99, 2523525266, https://doi.org/10.1029/94JC02257, 1994.

Kim, C.-K. and Park, K.: A modeling study of water and salt exchange for a micro-tidal, stratified northern Gulf of Mexico estuary, J. Marine Syst., 96-97, 103-115, https://doi.org/10.1016/j.jmarsys.2012.02.008, 2012.

Kuitenbrouwer, D., Reniers, A., MacMahan, J., and Roth, M. K.: Coastal protection by a small scale river plume against oil spills in the Northern Gulf of Mexico, Cont. Shelf Res., 163, 1-11, https://doi.org/10.1016/j.csr.2018.05.002, 2018.

Laurent, A., Fennel, K., Hu, J., and Hetland, R.: Simulating the effects of phosphorus limitation in the Mississippi and Atchafalaya River plumes, Biogeosciences, 9, 4707-4723, https://doi.org/10.5194/bg-9-4707-2012, 2012.

Lehrter, J. C., Ko, D. S., Murrell, M. C., Hagy, J. D., Schaeffer, B. A., Greene, R. M., Gould, R. W., and Penta, B.: Nutrient distributions, transports, and budgets on the inner margin of a river-dominated continental shelf, J. Geophys. Res.-Oceans, 118, 4822-4838, https://doi.org/10.1002/jgrc.20362, 2013.

Lerczak, J., Geyer, W. R., and Chant, R. J.: Mechanisms driving the time-dependent salt flux in a partially stratified estuary, J. Phys. Oceanogr., 36, 2296-2311, https://doi.org/10.1175/JPO2959.1, 2006.

Li, Y., Nowlin Jr., W. D., and Reid, R. O.: Mean hydrographic fields and their interannual variability over the Texas-Louisiana continental shelf in spring, summer, and fall, J. Geophys. Res., 102, 1027-1049, https://doi.org/10.1029/96JC03210, 1997.

Lucena, Z. and Lee, M. T.: Characterization of Streamflow, Suspended Sediment, and Nutrients Entering Galveston Bay from the Trinity River, Texas, May 2014-December 2015, U.S. Geological Survey Scientific Investigations Report 2016-5177, Reston, Virginia, USA, 38, https://doi.org/10.3133/sir20165177, 2017.

MacCready, P.: Calculating estuarine exchange flow using isohaline coordinates, J. Phys. Oceanogr., 41, 1116-1124, https://doi.org/10.1175/2011JPO4517.1, 2011.

Martin, P. J.: Description of the Navy Coastal Ocean Model Version 1.0, NRL Report NRL/FR/7322-00-9962, Naval Research Laboratory, Stennis Space Center, MS, USA, 2000.

Nowlin Jr., W. D., Jochens, A. E., Dimarco, S. F., Reid, R. O., and Howard, M. K.: Low-frequency circulation over the TexasLouisiana continental shelf, in: Circulation in the Gulf of Mexico: Observations and Models, edited by: Sturges, W. and LugoFernandez, A., Geophysical Monograph Series 161, AGU, Washington, DC, 219-240, https://doi.org/10.1029/161GM17, 2005.

Oey, L.-Y.: Eddy- and wind-forced shelf circulation, J. Geophys. Res., 100, 8621-8637, https://doi.org/10.1029/95JC00785, 1995.

Oey, L.-Y. and Lee, H.-C.: Deep eddy energy and topographic Rossby waves in the Gulf of Mexico, J. Phys.
Oceanogr., 32, 3499-3527, https://doi.org/10.1175/15200485(2002)032<3499:DEEATR>2.0.CO;2, 2002.

Oey, L.-Y., Ezer, T., and Lee, H.-C.: Loop current, rings and related circulation in the Gulf of Mexico: A review of numerical models and future challenges, in: Circulation in the Gulf of Mexico: Observations and Models, edited by: Sturges, W. and LugoFernandez, A., Geophysical Monograph Series 161, AGU, Washington, DC, 31-56, https://doi.org/10.1029/161GM04, 2005.

Ohlmann, J. C. and Niiler, P. P.: Circulation over the continental shelf in the northern Gulf of Mexico, Prog. Oceanogr., 64, 4581, https://doi.org/10.1016/j.pocean.2005.02.001, 2005.

Rabalais, N. N., Turner, R. E., Justić, D., Dortch, Q., Wiseman, W. J., and Sen Gupta, B. K.: Nutrient changes in the Mississippi River and system responses on the adjacent continental shelf, Estuaries, 19, 386-407, https://doi.org/10.2307/1352458, 1996.

Rabalais, N. N., Turner, R. E., and Scavia, D.: Beyond science into policy: Gulf of Mexico hypoxia and the Mississippi River, BioScience, 52, 129-142, https://doi.org/10.1641/00063568(2002)052[0129:BSIPGO]2.0.CO;2, 2002.

Rabalais, N. N., Turner, R. E., Sen Gupta, B. K., Boesch, D. F., Chapman, P., and Murrell, M. C.: Hypoxia in the northern Gulf of Mexico: Does the science support the plan to reduce, mitigate, and control hypoxia?, Estuaries Coasts, 30, 753-772, https://doi.org/10.1007/BF02841332, 2007.

Rayson, M. D., Gross, E. S., and Fringer, O. B.: Modeling the tidal and sub-tidal hydrodynamics in a shallow, micro-tidal estuary, Ocean Model., 89, 29-44, https://doi.org/10.1016/j.ocemod.2015.02.002, 2015.

Rego, J. L. and Li, C.: Storm surge propagation in Galveston Bay during Hurricane Ike, J. Marine Syst., 82, 265-279, https://doi.org/10.1016/j.jmarsys.2010.06.001, 2010.

Rong, Z., Hetland, R. D., Zhang, W., and Zhang, X.: Currentwave interaction in the Mississippi-Atchafalaya river plume on the Texas-Louisiana shelf, Ocean Model., 84, 67-83, https://doi.org/10.1016/j.ocemod.2014.09.008, 2014.

Sebastian, A., Proft, J., Dietrich, J. C., Du, W., Bedient, P. B., and Dawson, C. N.: Characterizing hurricane storm surge behavior in Galveston Bay using the SWAN + ADCIRC model, Coast. Eng., 88, 171-181, https://doi.org/10.1016/j.coastaleng.2014.03.002, 2014.

Shchepetkin, A. F. and McWilliams, J. C.: The regional oceanic modeling system (ROMS): A split-explicit, free-surface, topography-following-coordinate oceanic model, Ocean Model., 9, 347-404, https://doi.org/10.1016/j.ocemod.2004.08.002, 2005.

Stanev, E. V., Grashorn, S., and Zhang, Y. J.: Cascading ocean basins: Numerical simulations of the circulation and interbasin exchange in the Azov-Black-MarmaraMediterranean Seas system, Ocean Dynam., 67, 1003-1025, https://doi.org/10.1007/s10236-017-1071-2, 2017.

Umlauf, L. and Burchard, H.: A generic length-scale equation for geophysical turbulence models, J. Mar. Res., 61, 235-265, https://doi.org/10.1357/002224003322005087, 2003.

Wang, D.-P., Oey, L.-Y., Ezer, T., and Hamilton, P.: Near-surface currents in DeSoto Canyon (1997-99): Comparison of current meters, satellite observation, and model simulation, J. Phys. Oceanogr., 33, 313-326, https://doi.org/10.1175/15200485(2003)033<0313:NSCIDC>2.0.CO;2, 2003. 
Wang, L. and Justić, D.: A modeling study of the physical processes affecting the development of seasonal hypoxia over the inner Louisiana-Texas shelf: Circulation and stratification, Cont. Shelf Res., 29, 1464-1476, https://doi.org/10.1016/j.csr.2009.03.014, 2009.

Willmott, C. J.: On the validation of models, Phys. Geogr., 2, 184194, https://doi.org/10.1080/02723646.1981.10642213, 1981.

Ye, F., Zhang, Y. J., Wang, H. V., Friedrichs, M. A. M., Irby, I. D., Alteljevich, E., Valle-Levinson, A., Wang, Z., Huang, H., Shen, J., and Du, J.: A 3D unstructured-grid model for Chesapeake Bay: Importance of bathymetry, Ocean Model., 127, 1639, https://doi.org/10.1016/j.ocemod.2018.05.002, 2018.

Zavala-Hidalgo, J., Morey, S. L., and O'Brien, J. J.: Seasonal circulation on the western shelf of the Gulf of Mexico using a high-resolution numerical model, J. Geophys. Res., 108, 3389, https://doi.org/10.1029/2003JC001879, 2003.

Zavala-Hidalgo, J., Gallegos-García, A., Martínez-López, B., Morey, S. L., and O'Brien, J. J.: Seasonal upwelling on the western and southern shelves of the Gulf of Mexico, Ocean Dynam., 56, 333-338, https://doi.org/10.1007/s10236-006-0072-3, 2006.

Zhang, X., Hetland, R. D., Marta-Almeida, M., and DiMarco, S. F.: A numerical investigation of the Mississippi and Atchafalaya freshwater transport, filling and flushing times on the Texas-Louisiana shelf, J. Geophys. Res., 117, C11009, https://doi.org/10.1029/2012JC008108, 2012.
Zhang, Y. and Baptista, A. M.: SELFE: A semi-implicit Eulerian-Lagrangian finite-element model for crossscale ocean circulation, Ocean Model., 21, 71-96, https://doi.org/10.1016/j.ocemod.2007.11.005, 2008.

Zhang, Y. J., Ateljevich, E., Yu, H. C., Wu, C. H., and Yu, J. C. S.: A new vertical coordinate system for a 3D unstructured-grid model, Ocean Model., 85, 16-31, https://doi.org/10.1016/j.ocemod.2014.10.003, 2015.

Zhang, Y. J., Ye, F., Stanev, E. V, and Grashorn, S.: Seamless cross-scale modeling with SCHISM, Ocean Model., 102, 64-81, https://doi.org/10.1016/j.ocemod.2016.05.002, 2016.

Zeng, X., Zhao, M., and Dickinson, R. E.: Intercomparison of bulk aerodynamic algorithms for the computation of sea surface fluxes using TOGA COARE and TAO data, J. Climate, 11, 2628-2644, https://doi.org/10.1175/15200442(1998)011<2628:IOBAAF>2.0.CO;2, 1998. 